\title{
Experts' Personal Metaphors and Similes about Language Learning Strategies
}

\author{
Rebecca L. Oxford, Alabama A \& M University, USA \\ Ana Longhini, University of Rio Cuarto, Argentina \\ Andrew D. Cohen, University of Minnesota, USA \\ Ernesto Macaro, Oxford University, UK \\ Carol Griffiths, Yeditepe University, Turkey \\ Vee Harris, Goldsmiths College, University of London, UK
}

\begin{abstract}
This article examines many instances of figurative language employed by six international experts to describe language learning strategies and their involvement with such strategies over the lifespan. The first stage of analysis showed that the experts' metaphors and similes were associated with (a) creative construction; (b) food and liquid; (c) movement and stasis; (d) music; (e) awakening, seeing, enlightening, and illuminating; (f) sports and business; (g) animals; and (h) temperature. The next stage of analysis condensed the themes into the following larger themes: (a) awakening to strategies for the first time, (b) receiving and giving powerful gifts along the journey, and (c) learner self-

management. The overarching theme, which emerged in the third and final stage of analysis, was the urgent necessity of understanding learning strategies and using appropriate theories to explain them.
\end{abstract}

\section{Introduction}

Second and foreign language (L2) learning strategies are the steps or actions that a learner consciously takes to improve and regulate his or her language learning (Cohen \& Macaro, 2007; Griffiths, 2008; Oxford, 2011). Learning strategies can make language learning more effective, efficient, and enjoyable (Oxford, 1990a). This article answers the following questions: Do learning strategy experts depict those strategies in figurative language, such as metaphor and simile? If so, what metaphors and similes do they employ and why? Using contributions from six international specialists in learning strategies, this article presents a number of strikingly different ways in which learning strategies are depicted by means of figurative language.

\section{Review of the Literature}

This research review discusses metaphors and similes and how these have been used to date in discussions of language learning strategies. 


\section{Metaphors and Similes}

Metaphors and similes are part of figurative language, i.e., language using figures of speech that depart from the literal meaning. The word "figurative" implies images or pictures used for special effect, but it figurative language can also help us experience other senses as well, such as hearing, touch, and taste, and it can also make us experience movement.

A metaphor is a figure of speech in which a comparison - actually an equivalency is made with something that seems, at first blush, unrelated to it. The term metaphor comes from Greek metaphora, meaning "a transfer," which is based on metapherein "transfer, carry over; change, alter," from a combination of meta (over, across) and pherein (to carry or bear) (Harper, 2012). An active metaphor is an equivalency that is often highly creative, fresh, and even dazzling. Dead metaphors are metaphors that have, through great use, made their way into normal language and are no longer considered metaphors, as in "This association is hereby incorporated" (association = lit., placed into a physical body). Dying metaphors are those that have become more like clichés, as in "Watching the movie is a cool" (movie watching = cool, an overly employed phrase).

Metaphors have three parts: the topic, the vehicle, and the grounds of similarity. In the well-known metaphor "love is a rose" (Ronstadt, 1976/1990), love is the topic, and rose is the vehicle. The grounds - how the two are alike (the rose has beauty and painful thorns, and love offers beauty and pain) - are frequently understood rather than explicitly stated. For more on metaphor, see Gordon (1978), Lakoff and Johnson (1980), and Stight (1979). In contrast to metaphor, simile is a slightly weaker form of comparison. A simile includes words such as "like" or "similar to," as in Robert Burns' song "O my Luve's like a red, red rose ...," published again two hundred years later (Burns, 1994).

\section{Metaphors and Similes about Learning Strategies}

Though metaphors have rarely been systematically studied in research on language learning strategies, they are present and plentiful. This section presents examples of these metaphors. 
Orchestrating. The musical metaphor of "orchestrating" has been employed to imply that the learner can use strategies in a coordinated way. For instance, Vandergrift (2003) talked about orchestrating strategy use for listening. Anderson $(1991,2008)$ indicated that it is important for learners to orchestrate different types of strategies for best effect. Oxford (2011b) mentioned the metastrategy of orchestrating other strategies.

Tools. As noted by O’Malley, Chamot, Stewner-Manzanares, Kupper, and Russo (1985), learning strategies can be "an extremely powerful learning tool" (p. 43). Oxford (1990) highlighted strategies as tools for creating and strengthening schemata, i.e., mental frameworks. In a different article in this special issue (Oxford, Rubin, Chamot et al.), Nel mentioned that learning strategies "addressed a crucial aspect needed by L2 learners in their language learning toolbox," while Gunning cited "tools" related to strategies three times, Lavine and Rubin did this once each, and a reference related to Chamot's story (White, Schramm, \& Chamot, 2007) cited a strategy-research toolbox once.

Weaving. In the visual metaphor of the tapestry of language learning, learning strategies are an important strand (see Scarcella \& Oxford, 1992). The overall tapestry reflects a systems approach to language learning, with many components (e.g., learning strategies, learning styles, and motivation) woven together and influencing each other. Certain influential components (e.g., gender, nationality) relatively fixed, while others - learning strategies in particular - are flexible and can be optimized.

Depth. Another metaphorical descriptor of strategies involves depth. To aid in building schemata and retaining information, successful learners employ deep processing strategies, such as metacognitive strategies (e.g., planning, organizing, monitoring, and evaluating) and cognitive strategies (e.g., reasoning, comparing, contrasting, relating, and synthesizing) for strongest retention of information. Other students employ achievement strategies, which primarily help to achieve good grades or impress the teacher, though some learning also occurs; and less dedicated students employ surface strategies, e.g., repeating without understanding and memorizing for the short term only (Ehrman, 1996; Schmeck, 1998).

Weight. Cognitive load is a weight metaphor signifying the intellectual demands placed on learners' working memory. If the load is too great or not handled well, many 
learners become anxious and cannot adequately develop their schemata. Three types of cognitive load exist (Clark, Nguyen, \& Sweller, 2005; Oxford \& Lin, 2011). Intrinsic load refers to the complexity of information elements. To deal with intrinsic load, strategic language learners organize the information into easy-to-remember chunks. Extraneous load, which results from poor design of materials, leads to split attention, which can be overcome by separating relevant from irrelevant data. Germane load creates helpful demands on working memory, such as calling for the use of multiple senses.

Investment. The business metaphor of investment has been used in a sociocultural sense. Learners show different degrees of investment and participation, largely based on whether their learning situations are fraught with struggle and discrimination (Canagarajah, 1993; Norton, 2001; Norton \& Toohey, 2001, 2006). In situations in which social struggle is not as predominant, individuals often feel more free to invest in learning the L2, and Oxford (2011b) maintained that these students generally use learning strategies more often and to greater effect.

In short, a range of metaphors and similes is present in the area of language learning strategies. The following section explains the methodology of the current study.

\section{Methodology}

The six essays in this article were chosen because they were filled with metaphors and similes about learning strategies and closely related topics. Using a grounded theory approach, the first author (Oxford) analyzed the content of the six stories in the current article. At the open coding stage she identified the phenomena (e.g., metaphors and similes) in the narratives and categorized them into themes, continually comparing the data with the themes to ensure the best fit. The next stage, axial coding, allowed her to link the themes with each other in generic relationships. At the final stage, selective coding, she chose one theme as the most important and encompassing. The "raw" (unanalyzed) stories are presented next, followed by the findings of the analysis in the results section. 


\section{Six Stories}

The six stories were authored by Ana Longhini, Rebecca Oxford, Andrew Cohen, Ernesto Macaro, Carol Griffiths, and Vee Harris.

Ana Longhini's Story: There Will Always Be a Trace ...

Enseñarás a volar,

Pero no volarán tu vuelo.

Enseñarás a soñar,

Pero no soñarán tu sueño.

Enseñarás a vivir,

Pero no vivirán tu vida.

Sin embargo,

En cada vuelo,

En cada sueño,

En cada vida, perdurará por siempre la huella del camino enseñado.

Madre Teresa de Calcuta

Translation: You will teach (others) to fly, / But they will not fly your flight. / You will teach (others) to dream, / But they will not dream your dream. / You will teach (others) to live, / But they will not live your life. / Nevertheless, / In each flight, / In each dream, / In each life, there will always be a trace of what was taught. Mother Teresa of Calcutta

Argentina is going through a severe social and educational crisis. The educational policy of the 1990's proved to be a failure and the consequences are still being suffered. On top of that, the current economic policies do not consider the working class--there are no policies of inclusion--and the gap between the wealthy and the poor gets wider each day. About $50 \%$ of the students in public high schools do not graduate. When analyzing the multiple causes for the dropping out of school, sociologists claim that children from popular sectors do not have the "disposition" to learn that children from middle and upper classes have. 
Personally, I believe that in the foreign language classroom this "lack of disposition" can be translated into the impossibility of managing their learning. What most unsuccessful students lack is a command of L2 learning strategies, that is, they do not know how to learn. This being the scenario, it seems that never before in Argentina was there such an urgent need for teachers to appeal to resources that help them offer their students similar academic opportunities, that is, resources that help them equalize in the classroom what is so unequal in the outside world.

It is generally the case that when I expose these ideas to my graduate students, many of them high school teachers, they look as if the veil on their eyes had been lifted. And the idea of being able to empower their less successful students seems motivating enough for them to plunge in and see how far the topic of L2 learning strategies can go and to what extent it can be of use in the classroom. The graduate seminar I teach aims at reviewing language learning theories and integrating L2 learning strategies theory and practice. It examines the relation between learning style preferences and strategy use while considering the importance of affective factors. It also includes assessment and research of learning styles and strategies.

Before 1990 I had already been working with Gisi Sarig's (1987) taxonomy of reading strategies, an exhaustive, highly useful inventory included in Andrew Cohen's (1986) "Mentalistic Measures in Reading Strategies." But it was Rebecca Oxford's (1990a) book, Language Learning Strategies: What Every Teacher Should Know, that really made a difference in my teaching as well as in my researching. Simultaneously, also very influential were Andrew Cohen, Joan Rubin, Anita Wenden, Michael O’Malley and Anna Chamot, Carlos Manero Font, and César Coll, among others.

My interest in L2 learning strategies led me to meet prestigious scholars who are also wonderful people, with whom I have shared important academic events in different parts of the world and who kindly accepted to come to my school for various opportunities. In 1997 I took a Strategies-Based Instruction seminar at University of Minnesota, held by Andrew Cohen, with Rebecca Oxford as guest scholar. The following year I invited Andrew to Río Cuarto to lead a workshop, and later Rebecca came to teach a seminar for our master's 
program. I was convinced that if faculty and students at Universidad Nacional de Río Cuarto had the chance to be introduced into the topic of learning styles and L2 learning strategies by these specialists, the impact on their pedagogic practice would be very significant.

Undoubtedly, an inflection point in my career was the time I spent working with Rebecca Oxford at University of Alabama, with a Fulbright research grant. There I participated in a large-scale study on learner narratives. I cherish the long and illuminating disquisitions we had over the narratives while analyzing the data (see Oxford, Tomlinson, Barcelos, Harrington, Lavine, Saleh, \& Longhini, 1998). Two years later, a visiting Fulbright scholar who soon became a dearest friend, Joan Carson from Georgia State University, came to teach two courses in our master's program. With Joan I conducted a diary study (Carson \& Longhini, 2002) about her acquisition of the Spanish language during the three months that she spent in Argentina. Analyzing Joan's diary entries -- where she wrote, on a daily basis, about her experiences in developing the foreign language, Spanish, in which she was immersed -- was really fascinating for someone interested in looking for spontaneous utilization of language learning strategies and language use strategies.

I do not work alone. I have always counted on a research team, most of them former students of mine, to whom, I think, I succeeded in transmitting my enthusiasm for the topic and to whom I am indebted. They have all become knowledgeable in L2 learning strategies and have incorporated them into their regular courses at the teacher training program at Universidad Nacional de Río Cuarto as well as in graduate seminars and workshops that they teach in and out of town.

I have co-authored several EFL manuals for university students of English for specific purposes (ESP) and for high school students. In all of them the main aim has been to foster the application of strategies that render the students more independent learners of English. I have presented papers about my research findings at national and international events. Most of them were turned later into articles published in specialized journals like MEXTESOL and other local research journals. During all this time I have been applying L2 learning strategies in my classes at the teacher training program, where I teach the Practicum, as well as in my ESP classes for the Humanities major undergraduate programs. I 
have also been busy organizing and teaching in-service workshops and extracurricular seminars about learning styles and L2 learning strategies at the request of schools other than mine.

Our research has been in the most part quasi-experimental. We have used quantitative and qualitative techniques because I do believe in the strength of mixed methods. I have also conducted diary and case studies. As for the questions addressed, they have been, for the most part, related to EFL learning strategy instruction, learning styles and affective factors. They look at issues typical of our EFL situation for which we would like to have a solution, or at least be better equipped. In some cases we have used instruments available in the literature, such as Oxford's Style Analysis Survey (1993, 1995) and Strategy Inventory for Language Learning (Oxford, 1990b), Horwitz's Beliefs and Attitudes for Language Learning Inventory and Anxiety Scale (see Horwitz, 1985, 1987, 1988, 1999, 2008; Horwitz, Horwitz, \& Cope, 1986), or the Motivation Scale (in Dörnyei, 2005). At other times we were obliged to develop and validate our own ad hoc instruments. We developed, for example, Likert scales to measure the attitudes toward self-concept and toward educational technology. Our ongoing study looks at the relation between beliefs and reading practices of freshmen from the EFL Teaching Training Program.

The kind of strategy instruction preferred for my EFL and ESP courses, as well as for the treatment designed for our various quasi-experimental studies, is what Brown and Palincsar (1982) referred to as "completely informed." Our strategy instruction is based on a selection of strategies from Oxford's (1990a) typology. On each occasion, I select the strategies that lend themselves better for helping students achieve the aims of the course. Some of them have to be slightly adapted to fit our culture, and they are complemented with others that emerge from the situation, always considering the task at hand. I teach my students about the nature of strategies, their significance, how to use them, how to monitor them, how to evaluate them, and how to transfer them. I integrate strategies into course materials and I encourage students to discuss and reflect on their use and applicability for further transfer to the learning of contents. I try to make sure, through examples taken from 
everyday life, that students grasp the concept of "learning strategy" and, more specifically "L2 learning strategy," before I focus on specific strategies for listening, reading, speaking or writing. I am quite successful in getting students to conceptualize "L2 learning strategy" and in conveying the real value of strategy use. This occurs if I first get students to reflect on the development of any of their L1 language skills, let's say listening: what it implies, how it is done, and when it is successfully accomplished. Once I raise their consciousness of the development of their L1 linguistic skills, I can start speaking of English [L2] skills and the affective factors related to them.

If students "complain" about not being able to understand the speaker on the tape or on the screen, for example, we analyze the possible reasons that could be preventing them from understanding and then relate the situation to a hypothetical or experienced $\mathrm{L} 1$ situation. This is done for the students to reflect on what they mean by "I cannot understand anything" when listening to English, and how different their perception would be in their native language, even with the same amount of "understanding." I always find it useful to speak about my own language learning history as a way of illustrating the theoretical concepts, and also for students to know that I share their feelings. Once the students, adolescents and adults alike, become familiarized with L2 learning strategies, they bring to class comments about how they apply these strategies not only for improving their English but in other aspects of life related to learning or communicative situations. When this happens, I feel that I have achieved my aim, that the new knowledge has been personalized, and that it has finally become totally significant.

The best part of teaching students how to learn is that it is really rewarding. I had been piloting some strategy materials and the think-aloud technique for modeling mental processes in a fifth year of high school. The history teacher came into the classroom one morning announcing that she would teach them "how to learn," and one of the students responded "Too late, Mrs. Pérez. We already learned that with the English teacher". The anecdote was told to me by one of the participants ten years later, and he still vividly remembered the strategy instruction I had given him. 


\section{Rebecca Oxford's Story: My Experiences with Learning Strategies}

As a teenager, I used many learning strategies to help me learn Latin. For instance, I created charts for Latin grammar, and I wrote lists of vocabulary words, which I then clustered into meaningful groups. Later, while learning Russian as a university freshman, I held onto these two learning strategies for dear life, as though they were the only ones on earth. Although they fostered grammar learning and vocabulary development, these strategies actually hindered my Russian communication. Fortunately, one strategy that certainly helped with Russian language speaking was drinking beer with my Russian teacher and fellow students at a local bar while chatting in Russian.

Strategies involving rhythm and visual imagery helped me considerably in learning languages. Thinking back again to my high school experience, I learned Latin sentence structure and the flow of that language through paying close attention to the incredible music of Virgil's Aeneid (see the English edition, Virgil, 2006), the story of Aeneas and his adventures. I will never forget crucial sentences of that great work, which starts with the cadences of war: Arma virumque cano, pater Aenas (Arms and the man I sing, father Aeneas . .. .). Later, when I studied German at the university, I often used the music-and-rhythm technique to learn German, though the sounds were actually much better than the stories whose meaning they brought forth into the world. Intended to be humorous, the German workbook sentence, Schade für die armen Fische (too bad for the poor fishes), remains in my lexical memory because of the rhythm, not because of the sentence's meaning. In graduate school, while reading a much more profound German work, Franz Kafka's 1915 check story Die Verwandlung (The Metamorphosis, Kafka, 1995), in which traveling salesman Gregor Samsa turned into a cockroach, I used the shocking verbal images to carry me along and to help me learn vocabulary as I went. All this time, I was unaware of the term learning strategies, although I seem to have been a fairly prolific user.

In my informal learning of Spanish, I read newspapers, intentionally listened to snippets of language on public transit, and employed any other possible sources to help me learn vocabulary and discover how Spanish language words were put together into sentences and paragraphs. I realized that finding and using resources was a strategy, which helped me 
considerably when traveling to Central and South America to give lectures on language teaching and expand my minimal Spanish knowledge. Subsequently a publisher asked me to help write the learning strategies sections of a three-volume Spanish textbook series, and I was stunned to realize that I could successfully do so with the help of a grammar book. When I went to Brazil, I parlayed my basic understanding of Spanish into reading newspapers and listening to conversations in Portuguese.

The United States Department of Defense invited me to write a review of the literature on learning strategies and to create a questionnaire for assessing language learning strategies. I felt deeply honored and very excited by this challenge. The resulting questionnaire, known as the Strategy Inventory for Language Learning or the SILL, which was published in my first book on learning strategies (Oxford, 1990b), has been widely used in a variety of languages around the globe. Later I edited another book on learning strategies (Oxford, 1996) and wrote another book expanding that theme (Oxford, 2011b). Learning strategies have empowered me in many aspects of my language learning, regardless of the language involved. Some aspects of language learning, such as understanding oral language, are still difficult for me, so I have to use many listening strategies to do well in that crucial area. Many of my most helpful listening strategies were shown in Oxford (1990a).

Because some people do not find the concept of learning strategies to be intuitive, my close colleagues and I discovered metaphorical ways to describe those strategies. For example, we (Oxford \& Nyikos, 1989, p. 295) used a spiral image to explain that strategy use is related to proficiency and other positive variables: "We would expect that use of appropriate strategies leads to enhanced actual and perceived proficiency, which in turn creates high selfesteem, which leads to strong motivation, spiraling into still more use of strategies, great actual and perceived proficiency, high self-esteem, improved motivation and so on."

In my most recent book on learning strategies (Oxford, 2011b), I showed different types of learning strategies as dynamic cogs that interlock with each other and create motion progress in learning. The cogs are cognitive learning strategies, affective (emotional and motivation-related) learning strategies, and sociocultural-interactive learning strategies. Not 
only do these three cogs interact to create motion, but they are also strongly influenced by metastrategies, such as planning, organizing, monitoring, and evaluating.

Csíkszentmihály's (2008) idea of flow - a subjective sense of joy, motivation, competence, confidence, and complete immersion in a task - can be an outcome of learning strategy use (Oxford, 2012c). Becoming a strategic learner can lead to a state of flow, in which enjoyment and achievement are powerful. Similarly, Maslow's (1964, 1970, 1971) concept of peak experiences refers to moments of self-actualization in which the individual experiences a tremendous sense of happiness, well-being, wonder, awe, and love and sees the world in a profound way. Using personal narratives from non-Chinese learners of Mandarin language and Chinese culture, I presented evidence that in certain situations, strategically attuned language learners can experience peak experiences in learning a language (Oxford, 2012c).

Language learning strategies can help learners overcome problems and difficulties, so I have used a photographic metaphor to represent learning strategies (e.g., Oxford, 2011a, 2012b): a horse working with a jockey jump over great obstacles. Because language learning involves working with new and difficult sounds, I created another photographic metaphor of learning strategies: a plane breaking through the sound barrier (Oxford, 2011a, 2012b). Next I offered a visual metaphor for achieving a level of foreign or second language communication that allows great enjoyment: a drawing of a beautiful woman lovingly singing into a microphone (Oxford, 2011a, 2012b).

Additionally, language learning strategies can help people go places they could not otherwise go and accomplish things they could not otherwise accomplish. I used the metaphor of a man walking on the moon for the first time, because learning strategies help learners develop the skill and courage to explore new places inside themselves and in other cultures as they learn languages (Oxford, 2011a, 2012b).

Metaphors about learning strategies can involve temperature. I discussed "hot cognition," which in my view involves learning strategies, motivation, and information integration and transformation in a given sociocultural context (Oxford, 2009, 2012a, 2012c). This concept builds on the work of William James (1910/1987), who described volition as the "hot" merger of personal desire, excitement, will, and tension, creating a higher level of 
energy. Pintrich, Marx, and Boyle (1993) explained "hot conceptual change" or "hot cognition" as including motivational beliefs, which give the necessary heat and spark to both thinking and learning. Pintrich et al. rejected a "cold version" of learner cognition, i.e., completely rational and affect-free learning. Lakoff and Turner (1989) also portrayed something more valuable than "cool reason" in their volume.

A graduate student, Kyoung Rang Lee, and I portrayed journeying through the landscape of language learning (Oxford \& Lee, 2007). On this journey, successful learners develop new aspects of their identity, explore and enhance their motivation, and gain selfregulation through the use of a range of learning strategies relevant to varied social contexts. We concluded that learners "must employ appropriate behaviors (for instance strategies ... ) and utilize available facilitating opportunities afforded by the learning situation ... in order to traverse the landscape and arrive at the desired learning destination. Good language learners are those who manage this difficult journey successfully" (pp. 314-315).

I once paraphrased Alice Koeller and described language learners by stating, "My purposes are the geography that marks out my line of travel toward the knowledge I want to have" (Oxford, 2011b, p. 1 of the final chapter). Lakoff and Turner (1989) suggested that thinking of life as purposeful leads us to believe that life has destinations and therefore has paths to those destinations, thus making a journey of life. Mythically speaking, the "hero's journey" involves traveling mentally, geographically, emotionally, and spiritually through difficulties - and eventually, for some people, attaining enlightenment (Campbell, 2008).

Though I would certainly not describe myself as being on a hero's journey, I have fortunately attained some degree of enlightenment about what learning strategies are and what they can do for language learners. Over time I have grown to think in increasingly metaphorical terms about learning strategies, because metaphors unlock the right side of the brain, i.e., the pictorial, rhythmic, and feeling side, while simultaneously addressing the left side of the brain, i.e., the more linear, verbal, and mathematical side. For this reason, metaphors are useful for the teaching of learning strategies to students and for leading professional development sessions for language teachers who are interested in learning strategies. 


\section{Andrew Cohen's Story: The Making of a Strategy Researcher}

You could say that my awakening about the role of learner strategies in L2 learning came a bit "late" in my life as a language learner - at the age of 26 , when I was three years into my doctoral work at Stanford University. I already had had four years of Latin, five years of French (two years of formal study and then three years using it as a vehicle for studying French literature), three years of Spanish (two of them as a Peace Corps Volunteer or PCV in rural community development on the High Plains of Bolivia), and two years of unschooled submersion in Aymara (while a Peace Corps volunteer on the High Plains). I had also had several months of Italian study during a summer in Grenoble after my freshman year in college and perhaps a half year of informal study of Quechua prior to my Peace Corps stint. And at the start of my doctoral work I had added my seventh foreign language, as I took a semester of Portuguese.

Did my late understanding of the role of learner strategies mean I hadn't systematically used strategies for language learning up until that point? I obviously had used strategies, because I was getting good results from my various ventures into language learning and use. But what was lacking was an awareness of just how to enhance my strategy use so as to get maximum benefit from it. So I was a strategy user but not an enlightened one. I would certainly not have had a rigorous metalanguage with which to pass along my insights about the strategies that "worked" for me.

It was in the middle of my stint as a doctoral student in international development education that Joan Rubin paid a several-month visit to the campus to write up a research study with my doctoral advisor, Charles Ferguson. While she was at Stanford, Joan also pursued an interest of hers to explore the nature of students' participation in language classes. She would sit in on French, German, and Spanish classes and follow what selected learners were doing in class by watching them as they attended to class activities. She listened attentively when individual students spoke up in class, observed what they wrote in their notebooks, and even took notes on what they were taking notes on. During the breaks, she would go up to the students she was observing and would ask them about 
things they had written down in their notebooks. She wanted to better understand their rationale for doing what she observed them to be doing.

Rubin and I would meet periodically for lunch and she would tell me a bit about what she was doing and what she was finding. I must admit that at first it seemed totally off the wall to me. Given the educational context at that time, it was like the Wright brothers telling people about their ideas for a “flying machine.” But it didn't take her long to convince me that she was on to something truly important, and I started thinking about learners and their approaches to learning. In fact, it was from interacting with Joan that I first began looking at language learner strategies, both personally and professionally.

When I taught ESL during my three UCLA years just after the doctorate, I had my students compare various versions of their writing, and I watched their strategies for doing this. So, my enhanced awareness about language learner strategies got me looking for ways to support learners in being more strategic. In this case, it was demonstrating to students how they could utilize strategies in order to get off the "writing plateau" they were stuck on and move to a new level in their English academic writing. I also used insights about strategies to help my ESL students articulate and then deal with the interlanguage rules that they had developed. I had learned about interlanguage from Larry Selinker (1972). I was then coached by Pit Corder (1967) about how to elicit from students the rules they used for their language performance. One Chinese ESL learner explained that a rule she used for assigning tense to the copula be was as follows: "If it refers to an attribute of something, it is present tense, regardless of whether that thing still exists." Hence, she would write sentences like, "Twenty-five years ago my dad had an old Chevrolet. It is blue." Once I discovered the source of deviant grammar behavior through her retrospective verbal report, I was able to support her in enlisting strategies for more appropriate tense use in English.

Over the years I preferred to reach out directly to L2 learners at all levels. I started by giving short sessions to learners, first for at least 10 years at a center in Netanya, Israel for intensive study of Hebrew. I would give a talk on strategies for improving the learning 
of a particular skill (e.g., vocabulary learning, reading, etc.) and then have discussion sessions entitled, "All you wanted to know about language learning but were afraid to ask" (included in Oxford, 1990a, pp. 223-224). Then when I returned to the US, I started giving talks and workshops to a cross-section of students at the University of Minnesota who came to a center for enhancement of learning across fields.

Starting in 2001, my efforts were channeled into a course entitled, "Practical Language Learning for International Communication." The course was being offered both fall and spring semesters for many years. Many participants in this course had study abroad experience or were planning for study abroad, though other participants used what they learn in the course for learning in the U.S. or for non-study trips to the country where the L2 is spoken (Paige, Cohen, Kappler, Chi, \& Lassegard, 2006).

I have also done research with Spanish immersion students at the elementary level, both to determine their language strategies for doing academic work, especially in mathematics, and then to engage in an intervention to see the impact of strategy instruction on enhanced performance in academic Spanish (Cohen \& Gómez, 2008). In July through August, 2007, I was engaged in the first-ever intervention in strategy instruction at the Concordia Language Villages, which are language immersion camps in northern Minnesota. This involved teaching strategies to 64 teen-age learners of Norwegian ("Norwegian villagers") in their one-month credit course at the summer language immersion camp, with credit-earning "villagers" in the Swedish and Danish programs as a control group. Such interventions might later be planned for the other 13 language immersion camps. The prospects of reaching thousands of youth this way are very exciting, since 9,500 youth participate in these language immersion camps every summer.

With regard to teacher development, aside from talks and workshops I have given over the years to teachers, I also developed with Susan Weaver a summer institute at the Center for Advanced Research on Language Acquisition (CARLA) at the University of Minnesota, "Improving Language Learning: Styles- and Strategies-Based Instruction." It began in 1994 with providing 30-hour teacher institutes focusing on strategy instruction. 
The institute continued every year since then. In the early years of the institute, Rebecca Oxford was a regular guest lecturer, and her participation helped to shape the content and direction of the institutes, for which I am most grateful. I also learned a good deal from her about language strategies, learning styles, and motivation. Using this knowledge, I rewrote the teachers' guide for the institute (Cohen \& Weaver, 2006).

I am very proud of the book on language learner strategies that Ernesto Macaro and I edited (Cohen \& Macaro, 2007) that grew out of an exciting meeting of world experts on language learner strategies who came together in a summer meeting at Oxford University a few years ago. The volume may well serve as a seminal work for what it intended to do, namely, bring the field of language learner strategies to a new level of conceptualization and refinement, with the first half of the book providing theoretical states regarding key issues in the field (e.g., strategy terminology, psychological and sociological perspectives, research methods, strategy instruction, and strategizing about grammar) and the latter half of the book offering reviews of research in a variety of skill areas (listening, reading, oral communication, writing, and vocabulary). Additional work has led to a second edition of my book on strategies in learning and using a second language (Cohen, 2011) and to creation of a grammar-strategies website for Spanish learners, evaluated in Cohen, Pinilla-Herrera, Thompson, and Witzig (2011).

Ernesto Macaro's Story: Insights about Strategies

Most people, when they talk about language learner strategies, refer to second language (L2) learning, not first (L1). And I guess that's absolutely right. Certainly in terms of our spoken first language it's unlikely that we learn to use strategies - not consciously, anyway. Now, first language literacy is another matter. I'm sure that 5 and 6 year olds are using all sorts of strategies when they first encounter written first language text. It doesn't need a international and sometimes bitter educational debate about phonics or whole-word reading to tell us that young children must be using sounding-out strategies early on for difficult words or are saying to themselves something along the lines of "I recognize the shape of that word, I've seen it before, what image does it bring into my head? Aah!" 
The point I'm trying to make is that in L1 learning, especially L1 literacy, strategies are being used. But it isn't until we encounter some kind of a problem - like the difficulty of learning a second language - that we become aware of the strategies that we have been using. And of course it is precisely because we are encountering a new language that we have so many more strategies at our disposal. It's like you've been playing with a small Lego set for a whole year and suddenly your pal brings round his much bigger set and you put it together with yours and, wow!, you create a whole new range of fantastic structures.

Anyway, that's what happened to me. I was seven years old and quite happily getting on with my L1 Italian literacy when mum and dad said that we were going to go live in England. I didn't speak a word of English so when I got there (here) I just sat in the classroom and listened to this stream of sound (mostly from the teacher!) and tried to visualize where the gaps might be. Later, when the gaps had become more obvious, I used my Italian to try and remember English spelling. You wouldn't believe me if I told you the way that I memorized the spelling of the word "thought"!

By the time I was thirteen the Brit educational system considered that I was worthy of being allowed to learn French. The other kids in the class just couldn't understand why I could work out all these obscure words like ombre, phare, and even peur. The last one is quite a jump from the Italian paura, but after a while you begin to see the patterns and you can predict pretty accurately what the word is in the other language. Having Italian as my (slowly fading) Li did cause some problems, though, like (a) French flowers ending up masculine and (b) being in the past somehow getting saddled with être as the auxiliary. But even these you could prompt yourself to get right, especially if you noticed your mistake (gap) enough when you made it.

At university, language laboratory classes (French) were very early in the morning. So I strategically avoided these. I had a big over-arching strategic plan: wait until the study abroad year and soak up the language along with the Provence sunshine. And it worked, much to the displeasure of my UK university tutors who felt I should learn French by ploughing through a grammar book! It worked because I did everything I could to meet and live with French people and just kept communicating, finding ways round my language problems, and lubricating any articulation difficulties with vin ordinaire. 
So that when I became a language teacher in secondary schools I had this large palette of strategies at my disposal. Of course I didn't know they were called strategies at the time. It was the early seventies, Joan Rubin's (1975) article hadn't even appeared and the good language learner was just a twinkle in monsieur Naiman's eye (see Naiman, Fröhlich, \& Todesco, 1975). But the three languages were all working together in my head, and I tried to put this across to the kids I was teaching in North London (when they weren't trying to kill each other or bribing me to take them out to play football instead of doing French) - that they could use what language they knew to their best advantage, think of clever ways of guessing words they didn't recognize, try to see patterns even in the ridiculous utterances of monsieur and madame Bertillon.

Big jump now to the early 1990s, and everyone is talking about strategies and processes and skills. However, it's also precisely at this time that (a) I decide that I want to go into teacher education and (b) the British government decides to issue a decree that no L1 is to be used in the foreign language classroom. Weird or what? Here's me who has built his reputation on using one language to help the other two, trying to be bilingual instead of monolingual, strategic instead of passive, and I'm being told that as a teacher (and teacher educator) I can't refer to another language when teaching a foreign one!

Later I had the honor of co-editing a significant volume on learning strategies with Andrew Cohen (Cohen \& Macaro, 2007) and the great pleasure of working with a team of international figures in the strategies field. Well, if you go to many of the chapters in that book you will see the influence (and the positive influence) of the L1 - the L1 as probably one of the main strategic tools to help us learn and use the second language!

Since then I have been convinced that language learner strategies are the essential ingredients in the language learning sandwich. If the filling is the linguistic knowledge, strategies are the bread that stops the filling from spreading uselessly all over your hands. The important thing is that without strategies, your linguistic knowledge (basically vocabulary and grammar) is pretty useless. It's what you do with your linguistic knowledge that counts.

On occasion I have been a bit critical of strategies literature (for example, Macaro, 2006; Macaro, Graham, \& Vanderplank, 2007). But if I have it's because I believe that we owe it to our 
learners (particularly our neglected young and beginner learners) to get it right. I see too many failing young people in UK language classrooms to risk getting the theory wrong.

So, yes, we do need to define more precisely what a strategy is. Yes, we do need to sort out the relationship between strategy use and success by finding out why people use strategies differently. Yes, we do need to relate strategies to specific tasks and then see how learners feel about those tasks (self-efficacy). And yes, we do need to get our strategy instruction programs right and show, consistently, that they work.

In my view, getting at the process of language learning (which is what strategy research is about) is what teachers should be doing. That's the way to help learners, not by giving them grades or even by telling them to "be more careful" with their French accents, but instead by asking them how they went about writing a composition or listening to a recording and then trying to suggest possible alternative or more complex (yes, and effortful) ways of doing it. If we are to assess our language learners, then this should be an assessment for learning, not for judging them [the learners], or separating them, or stopping them learning a language. Investigating their strategic behavior offers that assessment for learning opportunity. We need to convince our student teachers and experienced teachers to seize that opportunity. Carol Griffiths' Story: Metaphorical Ways of Looking at Learning Strategies

As Wenden (1985) reminds us, there is an old proverb which states: "Give a man a fish and he eats for a day. Teach him how to fish and he eats for a lifetime." Applied to the language teaching and learning field, this proverb might be interpreted to mean that if students are provided with answers, the immediate problem is solved, but if they are taught the strategies to work out the answers for themselves, they may be empowered to manage their own learning.

I learned about the importance of strategies at a relatively early age. Up until the time I was about twelve years old, my school life had been very happy. I had been blessed with patient teachers who encouraged me with praise and good advice. Therefore, I had done well at school and had enjoyed my time there. Shortly after my twelfth birthday, however, my father changed his job. My new school was very different from my old one. Instead of the kindly teachers I was used to, Miss Campbell was a strict disciplinarian who 
seemed to take great delight in finding fault with anything I did. She never called me by my name: I was always "the new girl" to her. Discipline could be extremely punitive, from writing out many pages of repetitive lines to long periods of detention, though only the boys got the strap, for which, at least, I was grateful.

Although I found the whole atmosphere of the school repressive, the main problem was the curriculum. My previous school had emphasized creativity and selfexpression, whereas my new school had a much more formal approach. I found myself being expected to answer questions on nouns, verbs, adjectives, adverbs, prepositions, subjects, objects and predicates. I had never even heard these terms, and had absolutely no understanding of what they meant. If Miss Campbell had been talking Martian I could hardly have been more bewildered. My grammatical ignorance proved to be fertile ground for Miss Campbell's ridicule, since she knew almost for certain that if she asked me a question I would get it wrong.

The time came for a big test which, it was announced, would be held the following Monday. Forlornly, I went to Miss Campbell to ask for help. With a sweeping gesture of impatience, she told me to ask one of the other pupils. The other kids, however, had better things to do than spend their lunchtime tutoring a newcomer. I took my textbook home on Friday night, and, without too much expectation of success, set to work to try to make sense of its contents. I read the definitions of the unfamiliar concepts, wrote them out to help myself remember them, read the examples, did the exercises and checked my answers from the back of the book. By means of these strategies I found myself gradually achieving some understanding of the subject.

By Sunday night, I found I could do the exercises and get most of them right, and on Monday I got full marks in the test. Miss Campbell seemed surprised and even a little disappointed: she now had to find someone else to serve as the object of her scorn. Although she never paid me the compliment of calling me by my name, I suppose I earned from her a kind of grudging respect for having achieved beyond her expectations. And although we never actually liked each other, at least she more or less left me alone after that. 
This was a most uncomfortable experience. However, it taught me a valuable lesson which I have never forgotten: in this life we are ultimately responsible for our own success or failure. Although other people, such as good teachers, can be very helpful, and can make the task easier and more enjoyable, in the end it is we who do the learning, and if we fail we must take the responsibility for it. But if we develop sound strategies which are helpful to us, which suit our learning style, and which are appropriate for the task at hand, there is almost nothing we cannot achieve with sufficient effort and determination.

Now, as a teacher, I try to remember it is my job not only to tell my students what to learn but how to go about it. They will not always have me to refer to, and, anyway, I am not always right and do not always have all the answers they need. Successful students develop their own strategies, of which using their teacher to good effect to promote their own knowledge is only one. Strategies can be "an extremely powerful learning tool" (O'Malley et al., 1985, p. 43). Teachers need to give their students the tools to manage their own learning, and show them how to orchestrate their strategy repertoires effectively. Returning to Wenden's quotation, although teachers might reasonably be expected to play the fishmonger's role to some extent by supplying the basic necessary knowledge, they should also be aware of the need to teach students how to catch their own fish.

Beyond a doubt the most successful learners I have ever known have been active strategy users. Nina, for instance, was 19 years old, and had already studied English for nine years in her native Germany when she arrived to start her English language course in New Zealand. She was already an advanced English learner. Nina reported highly frequent use of a large number of the L2 learning strategies itemized in the Strategy Inventory for Language Learning or SILL (Oxford, 199ob) and was also able to add a number of key strategies of her own to the SILL items. She is able to cope with a degree of uncertainty, and is especially aware of the importance of vocabulary and the usefulness of reading in English. When interviewed, Nina said that a key strategy she used was to always write down everything she learned, since this helped to fix it in her mind and meant she could revise and learn it later. She had found talking to people in English the most useful 
strategy as a means of improving speaking skills, an area in which she lacked confidence. She felt that the best way to overcome this difficulty with confidence was to stay in an environment where the language was spoken (e.g. New Zealand), preferably living with a native-speaking family (as she did), since this maximized opportunity for practice and meant that she had to make the effort to interact in English whether she wanted to or not. As she said after a potentially embarrassing communicative incident outside of school, "I encourage myself to speak English even when I am afraid of making a mistake." (For more details about Nina, see Griffiths, 2003).

Another highly active strategy user was 28 -year-old Kira from Japan. When he started his English language course in New Zealand, Kira was placed in a mid-elementary (second-to-bottom) class on the basis of school placement procedures. He wanted to learn English in order to obtain a new job and so that he could write English lyrics for songs which he could perform with the band he had in Japan. Although Kira had not studied English formally since leaving school and had "forgotten much," even at an early stage in his course he was a very confident speaker and managed to use his knowledge very effectively. He attributed this ability to having worked in a duty-free shop where he had to speak English to customers, and to having been in a band where he sang in English.

Like Nina, Kira was very focused: he knew what he wanted and he worked very hard. Staff members often mentioned having to evict him from the self-study room when they were locking up, long after most students had gone. He progressed exceptionally quickly through the levels of the school (two levels per month). Like Nina, Kira also reported highly frequent use of a large number of the SILL strategies, including a rating of 5 ("always or almost always") on all of the SILL's metacognitive strategies. He clearly emphasized strategies for managing the learning process.

Kira was very definite and specific about his key strategies. He said he watched TV as much as possible to practice listening and read newspapers. In order to re-activate the knowledge acquired in his school days, he spent two to three hours a day working on his grammar. In class he always sat next to the teacher, so that it was easy to ask questions, or 
next to the best speaker in the class, so that he could use the other student's knowledge to expand his own. He did homework and lesson revision every day and talked with his host family in the evenings. He used every opportunity to converse with native speakers such as taxi drivers and shop keepers and kept a special notebook in which he wrote sentences. Kira believed in writing full sentences in order to check the usage: isolated words and meanings he found insufficient. According to Kira, the responsibility for learning was basically the students', who needed to make positive efforts to learn if they were to be successful. However, he believed a teacher could be very helpful, especially by creating a good atmosphere, by providing useful feedback, and by acting as a reference.

Kira had an outgoing personality and showed real leadership among the other students, while his disciplined approach to his learning earned everyone's respect and helped him to achieve an all-round excellence. The likelihood that some of this success might be related to Kira's extensive repertoire of L2 learning strategies is suggested by the positive relationship which has been discovered between reported frequency of language learning strategy use and proficiency (e.g. Green \& Oxford, 1995; Griffiths, 2003). Also important may be Kira's ability to effectively orchestrate his large strategy repertoire (Oxford, 2011b).

Nina and Kira are living examples of the importance of taking an active approach to learning by means of strategies. These strategies allowed them to be self-regulated learners. Other influences on L2 learning include motivation, age, style, personality, gender, beliefs, culture, aptitude, as well as the nature of the learning target and of the learning situation, but the most proficient students appear to use strategies which enable them to work consciously on their L2 learning. Successful learners report using strategies to learn vocabulary, interact frequently with others, read the L2 while avoiding direct translation, tolerate ambiguity, understand language systems, manage their own learning, utilize available resources (such as TV, songs, and movies), and remain relaxed and positive.

By recognizing that "learning begins with the learner," Nyikos and Oxford (1993, p. 11) acknowledge the basic reality that, like the proverbial horse led to water but which must do 
the drinking itself, even with the best teachers and methods, students are the only ones who can actually do the learning. This is a reality which "every teacher should know" (Oxford, 1990a). As a result of their study, O'Malley et al. (1985, p. 43) concluded that many students used L2 learning strategies "inefficiently." They also found that teachers were generally not highly aware of their students' strategies. This old research finding remains uncomfortably true today, and much work remains to be done.

Vee Harris' Story: On My Strategy Journey

It's interesting to reflect on the strategies I'm using to reflect on my own personal journey through learning strategies research over more than 15 years! Evaluating my learning, encouraging myself and analysing and reasoning are high on the list, along with creating mental linkages across so many vivid memories!

The impetus to set off on the journey came in 1992. I ran a teacher training course for Modern Languages post-graduate students in London. I wanted to ensure that these students were exposed as soon as possible to the practical implications of developing autonomy in their pupils. So with the help of the Local Education Authority we set up a project where they would work alongside experienced teachers, who themselves were experimenting with fostering independent learning.

Watching the pupils during group work, I was really struck by the lack of what I then called "study skills." Faced with an unfamiliar word, even if it was a cognate, they simply gave up, appearing to feel that none of their existing knowledge could help them. Without such skills, they were ill-equipped to make the most of their learning opportunities. So with the support of my colleague, Michael Grenfell from Southampton University, I turned to research studies for some help. Oxford's (1990) and O'Malley and Chamot's (1990) books came to the rescue. But sometimes it is not enough to read; we need to experience things for ourselves.

Two events were significant for me. About the same time, I went to Kenya on holiday and struggled to remember how to say "see you later" in Swahili. I wrote down what it sounded like: "tutuanabadeye" and decided to try out strategies like association and imagery to help me remember it. So I drew a picture of a banana in a tutu with a black eye. The phrase stuck. Second, my daughter was studying French and would ask me to check her work. I became 
frustrated, because frequently she would only notice the errors if I asked her what was missing. But then I started to ask myself about exactly what I do when I check the letters I write to French friends before I send them off. More importantly, had I ever shared with my daughter what is involved in checking written work? So I was hooked!

Although these events had given me some valuable insights, they were mostly limited to the context of teaching a new language, French, to beginner learners. In 2000 I had the opportunity to coordinate a Council of Europe funded project to develop distance learning materials for adults, with a focus on "learning to learn languages." The challenge was to adapt existing models of strategy instruction to adults across Europe, learning a range of languages at very different levels and with very different levels of support. Members of our team came, for example, from Hungary and Lithuania, as well as from Austria and Iceland (Harris, Ingvadóttir, Jones, Neuburg, Palós, \& Schindler, 2001). My eyes were opened when we discussed the strategies needed for advanced learners of English and how we could help such learners without ready access to textbooks or computers and without teacher mediation to scaffold learner selfregulation. A further key question that emerged was whether some strategies were more suitable for beginners and other strategies for more advanced learners. This has continued to vex me, as you will see!

Sharing these insights with teachers in professional development sessions, whether in the UK or in Europe, was and continues to be a real challenge. Teachers struggle, for example, to see that the main point is not the 100 inventive ways they present new language to pupils but instead how to enable the pupils themselves to find appropriate personal strategies. Furthermore, teachers are highly constrained by having to meet government targets for examination success. These factors may prevent teachers from seeing that a long-term investment in teaching L2 learning strategies may be more productive than immediate measures to teach pupils to "jump through the hoops."

My own recent research, funded by the Society for Educational Studies, taught me the complexity of integrating strategy instruction for listening and reading into the French curriculum for 12-year-olds at two London secondary schools. The aim was to use investigate ways to improve French-learning performance and to encourage learners to transfer strategies 
across the L1 and the L2. Pupils were initially positive, but their motivation tailed off, partly because pupils were faced with the application of new strategies and with unfamiliar materials. We then developed an alternative and more successful approach, but it has helped me become aware of just how complex strategy instruction is and the need to help teachers, through professional development, to deal with this complexity. These insights have also raised questions about sessions with my student teachers. Reconciling government pressures to meet targets with genuine language learning appears to be an issue whether with pupils in schools or beginner teachers.

A further struggle has been to develop appropriate research measures with this younger group of near beginners in schools. Pupils rise to the challenge of "thinking aloud," although it is hard to find a balance between putting pupils at their ease and not "over-prompting."

I've also been curious about investigating whether there are individual differences in pupils' responses to strategy instruction according to their prior attainment, prior motivation level, socioeconomic background, gender, and bilingual/monolingual status. The three case studies Professor Grenfell and I explored in our 1999 book (Grenfell \& Harris, 1999) really highlighted for me the complexities of individual differences.

A very encouraging discovery, as yet unpublished, is that prior motivation level, socioeconomic background, and gender may not be as significant as expected. To my surprise, what did emerge were bilingual pupils' enhanced abilities in relation to listening skills (Harris \& Grenfell, 2006). The value of bilingualism has been underlined by studies which show that it facilitates the acquisition of a third language, but the actual strategies that enable bilingual students to learn an $\mathrm{L}_{3}$ are not yet fully explored. Our guess is that $\mathrm{L}_{3}$ acquisition is easier, since bilinguals have a better-developed use of strategies because of the resources, both psychological and social, of their home background. All three pupils interviewed for the project made extensive use of the strategy of substitution, whether in reading or in listening. This is one of my favorite quotes from one of the bilingual students, who talked about substitution:

I use the words that I do know, and the words that I don't, I put the "something" there instead of it. Think of what might go there in the space. Like if I know the first part of the sentence, like if they were saying "I work in", I would think of what sort of person they are, what 
their job could be, or I close my eyes, and sort of bring my spirit out, and get myself into that word, what it can mean (Grenfell \& Harris, 2006).

In looking back on my and others' research seems clear that strategy instruction can make a significant difference for pupils, although questions remain about which skill area is the most appropriate starting point. Related to this are issues raised by the link between L1 and L2 strategies. I really want to encourage teachers of the two languages to collaborate to make the links between the languages more explicit and to challenge students' perceptions that they "know" their mother tongue and have nothing more to learn about it.

It has also been illuminating to work with student teachers on the Community Languages course run by my colleague, Jim Anderson, and to explore what additional challenges are faced by pupils grappling for example with an unfamiliar script. We need to do a lot more work there. So I am really excited by the prospect of bringing together psychological and sociocultural perspectives on learning strategies and what it means to facilitate a "strategic classroom," where all the pupils share how they tackle a new language.

This has been a real journey of discovery for me. At every stage new questions emerge, and I am challenged to question my assumptions about what it means to learn and "know" a new language.

\section{Results of Three Stages of Analysis}

The above stories, which were written by six international experts in the area of learning strategies, are overflowing with figurative language. The metaphors and similes gave the stories deeper meaning, often related to the senses. Below are the results of the three stages of thematic content analysis.

Results of the First Stage of Analysis

The first stage of content analysis showed that figurative language was associated with the following eight themes, summarized in Table 1.

\section{>>>>>Insert Table 1 about here $<<<<<$}

\section{Creative Construction}

Many of the metaphors encompassed creative construction, particularly with help from tools and scaffolding. Citing O'Malley et al. (1985), Griffiths reminded us that 
"Strategies can be 'an extremely powerful learning tool." She also stated that "Teachers need to give their students the tools to manage their own learning." Harris noted that scaffolding was needed because, as she observed, “... students were ill-equipped [without the needed tools] to make the most of their learning opportunities." Macaro identified the first language "as probably one of the most strategic tools to help us learn and use the second language!" In discussing learning a new language after having learned another, and becoming aware of so many more strategies, he likened the situation to playfully constructing with Lego sets. He said, "It's like you've been playing with a small Lego set for a whole year and suddenly your pal brings round his much bigger set and you put it together with yours and, wow!, you create a whole new range of fantastic structures." For Macaro, creative construction was also possible through visual arts. As he stated, strategies were "a large palette" to enable painting in the new language.

\section{Food and Liquid}

Macaro also inserted a humorous metaphor involving food. Strategies provide structure for encompassing and channeling the student's rapidly growing linguistic knowledge, as he described:

... I have been convinced that language learner strategies are the essential ingredients in the language learning sandwich. If the filling is the linguistic knowledge, strategies are the bread that stops the filling from spreading uselessly all over your hands. The important thing is that without strategies, your linguistic knowledge (basically vocabulary and grammar) is pretty useless.

For Griffiths, learning strategies help students do more than assuage immediate hunger; instead, they help us eat for a lifetime. "As Wenden (1985) reminds us, there is an old proverb which states: 'Give a man a fish and he eats for a day. Teach him how to fish and he eats for a lifetime." By supplying the basic knowledge, teachers might be fishmongers to some degree, but "they should also be aware of the need to teach students how to catch their own fish."

In a simile, Griffiths talks about drinking. She notes the fundamental reality that students are "like the proverbial horse led to water but which must do the drinking itself." Even with the best instructional methodologies and the most expert teachers, students are the only ones who can actually do the learning. Drinking alcohol was mentioned by Macaro, who metaphorically described "lubricating articulation difficulties with vin ordinaire ...." Oxford emphasized the strategy of drinking beer with her teacher and co-learners. Sharing this form of sustenance helped 
the students speak Russian more effectively. Though her statement was more literal than figurative, it is implicit that alcohol drove away the anxieties and problems.

Liquid was used figuratively in other ways as well. Oxford mentioned "the flow of language” as she learned Latin. She also discussed Csíkszentmihály's (2008) metaphorical concept of "flow - a subjective sense of joy, motivation, competence, confidence, and complete immersion in a task" as a result of learning strategy use." Immersion itself is a metaphorical word used to indicate being completely covered by a liquid. As indicated above, Oxford used the term with reference to a task in general. Longhini and Cohen employed the word immersed or immersion in a language. Longhini mentioned her friend "developing the foreign language, Spanish, in which she was immersed." Cohen cited "research with Spanish immersion students at the elementary level" and "language immersion camps in northern Minnesota."

Three other metaphorical uses of liquid emerged. Macao described how one can "soak up the language." He also described how he "sat in the classroom and listened to this stream of sound (mostly from the teacher!).” Talking about teachers, Longhini stated the following: “And the idea of being able to empower their less successful students seems motivating enough for them to plunge in.”

\section{Movement and Stasis}

Both Longhini and Cohen emphasized the concept of flying. For Longhini, quoting Mother Teresa, "you will teach others to fly, even though they will not fly your flight [Enseñarás a volar, / Pero no volarán tu vuelo] exactly as you demonstrated." Also, "there will always be in the students a trace of what was taught [perdurará por siempre la huella del camino enseñado].” A flying machine is Cohen's simile for Rubin's ideas about the good language learner, which he initially considered weird but rapidly accepted as innovative and important: "Given the educational context at that time, it was like the Wright brothers telling people about their ideas for a 'flying machine.' But it didn't take her long to convince me that she was on to something truly important ....” At first he thought Rubin's ideas were "off the wall" (unsupported, hanging in space), but he found out that this judgment was wrong.

The journey is a powerful movement-attuned metaphor. Journey the most frequent metaphor in the story by Harris, who mentioned "my own personal journey through learning strategies research," "the impetus to set off on the journey," and "a real journey of discovery for me." Oxford referred to "journeying through the landscape of language learning, ... [where] successful learners develop new aspects of their identity, explore and enhance their motivation, and gain self-regulation 
through the use of a range of learning strategies relevant to varied social contexts... Good language learners are those who manage this difficult journey successfully ...." She also described "my line of travel," "a journey of life," and the mythical "hero's journey," in which experience and ultimate learning are gained.

In a story packed with motion metaphors, Oxford described the "strategy spiral," in which strategy use leads to greater proficiency, which in turn leads to greater self-esteem and greater motivation, which often stimulate greater strategy use, and so on. In addition, she employed a variety of other highly visual metaphors for learning strategies: dynamic cogs powering movement (different types of strategies that work together), breaking through the sound barrier (learning very new sounds because of strategies), the horse and the jockey jumping over obstacles (using strategies to overcome difficulties), the man walking on the moon (going to new places by means of strategies), and having peak experiences (moving to new heights and having exciting experiences because of strategies). She used photographs of most of these to capture the interest of audiences.

For Cohen, it was important to demonstrate to students "how they could utilize strategies in order to get off the 'writing plateau' they were stuck on and move to a new level in their English academic writing." They were at a point of stasis, stuck on a plateau, but strategies helped them move to a wholly new place.

Jumping had multiple meanings in the stories. Harris mentioned with displeasure "immediate measures to teach pupils to "jump through the hoops,"” i.e., do a lot of extra things to please someone in order to attain something desired. Macaro used the term "jump" in two different ways: "peur . . is quite a jump from the Italian paura" (showing grammatical differences) and "Big jump now to the early 1990s, and everyone is talking about strategies and processes and skills" (temporal and conceptual movement).

Another movement metaphor was "ploughing," i.e., making the ground ready for planting. Macaro's UK tutors preferred him to be "ploughing through a grammar book," but clearly his was not his personal desire. In Griffiths' story, grammar - or rather grammatical ignorance - was also a type of ground: "My grammatical ignorance proved to be fertile ground for Miss Campbell's ridicule, since she knew almost for certain that if she asked me a question I would get it wrong." Miss Campell's grammar lesson seemed like "talking Martian” at first, before little Carol Griffiths had ever seen a grammar text.

Stasis was a positive goal when Harris said, "I was hooked [captivated]!" She also used the term "stuck" in a positive way: "The phrase stuck [in my mind]." (In more literal, often less positive 
interpretations, hooked would mean caught by a hook and unable to get free, while stuck would mean jammed, caught, or held in an immovable position.)

\section{Music}

Music involves many types of movement (see above) but has its own special category here, due to the importance of the idea of "orchestrating strategies." Griffiths noted that strategy repertoires can be orchestrated or directed: "show them how to orchestrate their strategy repertoires effectively. .." and "effectively orchestrate his large strategy repertoire." To represent the joyful, communicative aspects of language learning strategies, Oxford metaphorically used the picture of a singing woman.

\section{Awakening, Seeing, Enlightening, and Illuminating}

Awakening, seeing for the first time, enlightening, and illuminating were all metaphoric themes in the stories. For example, Cohen described his "awakening about the role of learner strategies," which occurred in his twenties. Before that, he was an unenlightened user of strategies. The same can be said of Macaro as a child learning English and French in the UK, Harris as an adult traveling in Kenya, and Oxford learning languages in the US.

Harris remarked, "These individuals were awakening to strategies," and "My eyes were opened when we discussed the strategies needed for advanced learners of English and how we could help such learners ....” Longhini stated, “. . . when I expose these ideas to my graduate students, many of them high school teachers, they look as if the veil on their eyes had been lifted." Light and illumination played additional roles. Harris noted that "three case studies ... really highlighted [provided illumination] for me the complexities of individual differences," and she stated "It has also been illuminating to work with student teachers." For Longhini, "I cherish the long and illuminating disquisitions we had over the narratives while analyzing the data."

In Macaro's delightful turn of phrase, "the good language learner was just a twinkle in monsieur Naiman's eye ... ," meaning that the light had not yet dawned for L2 learning strategy research. In an implicit metaphor meaning life-bringing, but also perhaps suggesting light-bringing, Longhini described a "seminal work ... [to] bring the field of language learner strategies to a new level of conceptualization and refinement, ..."

Sports and Business

Harris used some sports metaphors -- struck and tackle - that have already become part of the language. She said, "Watching the pupils during group work, I was really struck by the lack of what I 
then called 'study skills." She also remarked on "how they tackle a new language." Cohen commented on being "coached [trained expertly] by Pit Corder."

Business metaphors also occurred. Cohen spoke of "my various ventures into language learning and use." Harris noted that "a long-term investment in teaching L2 learning strategies may be more productive." Oxford stated, "When I went to Brazil, I parlayed my basic understanding of Spanish into reading newspapers and listening to conversations in Portuguese."

\section{Animals}

Three examples of figurative language involving horses were given by Macaro ("somehow getting saddled with être as the auxiliary"), Griffiths ("like the proverbial horse led to water but which must do the drinking itself), and Oxford (the horse and jockey image). Fishing was a key metaphor for Griffiths, as shown earlier.

\section{Temperature}

Drawing on the work of William James and of Pintrich, Marx, and Boyle, Oxford focused on the heat of learning. Hot conceptual change, or hot cognition, includes "motivational beliefs, which give the necessary heat and spark to both thinking and learning." Like the others, Oxford rejected cold, solely rational, emotionless learning. Results of the Second Stage of Analysis

In the second stage, it was possible to combine some of the themes by looking at conceptual similarities. Table 2 displays the themes resulting from stage two of analysis.

\section{> > > > Insert Table 2 about here $<<<<<$}

\section{Awakening to Strategies for the First Time}

The narrators described using learning strategies before they had a name for them. Cohen mentioned that as a youth, "I was a strategy user but not an enlightened one." For Macaro, informal strategies that he created were of great utility before he knew anything about the research field of learning strategies. Harris described using strategies for remembering words while of holiday in Kenya. These individuals were beginning to awaken to strategies.

\section{Receiving and Giving Powerful Gifts along the Journey}

The continuing trace left by the teacher in the learner's mind is indeed a gift, and teachers' eyes can have their veil lifted as well (see Longhini's story). In addition, professionals who encounter and learn from each other receive gifts of knowledge and sensitivity. For instance, Cohen was struck by meeting and talking with Rubin for the first time, and he soon became enlightened about learning strategies. Longhini's strategy work in Argentina was enhanced by 
international visits from Cohen, Oxford, and Carson. For Oxford, hot cognition was a major gift from James and from Pintrich et al. to share with others. Harris' essay cited multiple points of learning and light while on her journey. Even Griffiths learned something valuable from Miss Campbell - how to avoid being stern and negative with students.

\section{Learner Self-Management}

Learner self-management emerged in several ways. The first involved the sense of movement: orchestrating strategy use into repertoires, flying one's own flight rather than that of another person, using strategies as construction tools or artistic palettes, and leaving an unhelpful plateau to move to a better place. The second sensory aspect of learner self-management involved gaining sustenance and relaxation, based on the metaphors of eating and drinking. In addition, learner self-management involved investment of time and effort and a sense of venturing. The Result of the Third Stage of Analysis

The third stage of analysis results in a single key theme, in this case stated literally rather than metaphorically: the necessity of understanding learning strategies and applying appropriate theories to explain them. The importance of theory was raised by Longhini, who taught strategy-based courses that integrate theory and practice. Macaro also emphasized the theory-practice link by saying, “... we owe it to our learners (particularly our neglected young and beginner learners) to get [the theory] right. I see too many failing young people in UK language classrooms to risk getting the theory wrong." Government policies, program evaluation, learning technologies, teacher development, learner development, and language teaching in general must reflect a clear understanding of language learning strategies and their foundational theories. See Table 3.

\section{>>>>> Insert Table 3 about here $<<<<<$ \\ Conclusion}

This research shows the value of exploring the narratives of strategy experts to unearth the metaphors and similes found there. Using the narratives of six strategy experts, eight strategyrelated themes emerged from these narratives: (a) creative construction; (b) food and liquid; (c) movement and stasis; (d) music; (e) awakening, seeing, enlightening, and illuminating; (f) sports and business; (g) animals; and (h) temperature. Through further analysis, these examples were combined into three main themes: (a) awakening to strategies for the first time, (b) receiving and giving powerful gifts along the journey, and (c) learner self-management. The final step of content analysis resulted in an overarching theme: the importance of understanding learning strategies 
and using appropriate theories to explain them. If this final theme were recognized, the quality of language teaching and learning would be likely to improve exponentially.

Qualitative analysis such as this can be accomplished with a range of learner narratives, such as language learning histories or learner diaries (see Oxford, 2012c; Oxford, Tomlinson, Barcelos et al., 1998). In addition to metaphors and similes regarding learning strategies, other elements the researcher might examine in learner narratives include overtly stated emotions, issues of motivation and demotivation, connections between learning strategies and styles, age and language learning, and, of course, sociocultural identities, given that language learning can be a site of social struggle for many learners (Norton, 2001; Oxford, 2011b).

\section{References}

Anderson, N.J. (1991, Winter). Individual differences in strategy use in second language reading and testing. Modern Language Journal, 75(4), 460-472.

Anderson, N.J. (2008). Metacognition and the good language learner. In C. Griffiths (Ed.), Lessons from good language learners (pp. 99-109). Cambridge: Cambridge University Press.

Brown, A. L. \& Palincsar, A. S. (1982). Inducing strategies learning from texts by means of informed, selfcontrol training. Topics in Learning and Learning Disabilities, 2(1), 1-17.

Burns, R. ( 1994). Selected poems. C. McGuirk (Ed.). New York: Penguin.

Campbell, J. (2008). The hero with a thousand faces: Collected works of Joseph Campbell. $3^{\text {rd }}$ ed. Novato, CA: New World Library.

Canagarajah, A.S. (1993). Critical ethnography of a Sri Lankan classroom: Ambiguities in opposition to reproduction through ESOL. TESOL Quarterly, 27(4): 601-626.

Carson, J.G. \& Longhini, A. (2002). Focusing on learning styles and strategies: A diary study in and immersion setting. Language Learning, 52, 401-438.

Clark, R.C., Nguyen, F., \& Sweller, J. (2005). Efficiency in learning: Evidence-based guidelines to manage cognitive load. New York: Wiley.

Cohen, A.D. (1986). Mentalistic measures in reading strategy research: Some recent findings. The ESP Journal, $5(2), 131-145$.

Cohen, A.D. (1990). Language learning: Insights for learners, teachers, and researchers. Boston: Heinle \& Heinle.

Cohen, A.D. (1998). Strategies in learning and using a second language. $1^{\text {st }}$ ed. Harlow, Essex, UK: Pearson Longman.

Cohen, A.D. (2011). Strategies in learning and using a second language. $2^{\text {nd }}$ ed. Harlow, Essex, UK: Pearson Longman. 
Cohen, A. D. \& Gómez, T. (2008). Towards enhancing academic language proficiency in a fifth-grade Spanish immersion classroom. In D. M. Brinton \& O. Kagan. (Eds.), Heritage language acquisition: A new field emerging. Mahwah, NJ: Lawrence Erlbaum.

Cohen, A.D. \& Macaro, E. (2007). Language learner strategies: Thirty years of research and practice. Oxford: Oxford University Press.

Cohen, A. D. \& Pinilla-Herrera, A. (2010). Communicating grammatically: Constructing a learner strategies website for Spanish. In T. Kao \& Y. Lin (Eds.), A new look at language teaching and testing: English as subject and vehicle (pp. 63-83). Taipei, Taiwan: The Language Training and Testing Center.

Cohen, A. D., Pinilla-Herrera, A., Thompson, J., \& Witzig, L. (2009, Nov.) Communicating grammatically: Evaluating a learner strategies website for Spanish grammar. Paper presented at the Annual ACTFL Convention, San Diego.

Cohen, A.D. \& Weaver, S.J. (2006). Styles- and strategies-based instruction: A teacher's guide. Minneapolis, MN: Center for Advanced Research on Language Acquisition, University of Minnesota.

Corder, S.P. (1967). The significance of learners' errors, International Review of Applied Linguistics, 5, 160170

Csíkszentmihályi, M. (2008). Flow: The psychology of optimal experience. New York: Harper.

Dörnyei, Z. (2005). The psychology of the language learner: Individual differences in second language acquisition. Mahwah, NJ: Erlbaum.

Ehrman, M.E. (1996). Understanding second language learning difficulties. Thousand Oaks, CA: Sage.

Gordon, D. (1978). Therapeutic Metaphors, Capitola, CA: Meta Publications.

Green, J. \& Oxford, R. (1995). A closer look at learning strategies, L2 proficiency and gender. TESOL Quarterly, 29(2), 261-297.

Grenfell, M. (2007). Language learner strategy research and modern foreign language teaching and learning. Language Learning Journal, 35(1), 9-22.

Grenfell, M. \& Harris, V. (1999). Modern languages and learning strategies in theory and practice. London: Routledge.

Griffiths, C. (2003). Patterns of language learning strategy use. System, 31, 367-383.

Griffiths, C. (2008). Lessons from good language learners. Cambridge, UK: Cambridge University Press.

Harper, D. (2012). Metaphor. Online dictionary of etymology. http://www.etymonline.com/index.php?allowed_in_frame=o\&search=metaphor\&searchmode= none 
Harris, V. \& Grenfell, M. (2006, Sept.). Strategy use of bilingual learners: a research agenda. Paper presented at the conference of the British Educational Research Association, University of Warwick, UK.

Harris, V., Ingvadottir, H., Jones, B., Neyburg, R., Palos, I, \& Schindler, I. (2001). Helping learners learn: Exploring strategy instruction in languages classrooms across Europe. Graz: ECML.

Horwitz, E.K. (1985). Using student beliefs about language learning and teaching in the foreign language methods course. Foreign Language Annals, 18, 333-340.

Horwitz, E.K. (1987). Surveying learner beliefs about language learning. In J. Rubin \& A. Wenden (Eds.), Learner Strategies in Language Learning (pp. 119-129). Upper Saddle River, NJ: Prentice-Hall.

Horwitz, E.K. The beliefs about language learning of beginning university foreign language students. The Modern Language Journal, 1988, 72, 182-193.

Horwitz, E. K. (1999). Cultural and situational influences on foreign language learners' beliefs about language learning: A review of BALLI studies. In A. Wenden (Ed.), special issue of System, 27, 557576.

Horwitz, E. K. (2008). Why student beliefs about language learning matter. The evolution of the Beliefs about Language Learning Inventory. In J. Siskin (Ed.) Issues in Language Program Direction (pp. 28). Alexandria, VA: American Association of University Supervisors and Coordinators.

Horwitz, E.K., Horwitz, M.B., \& Cope, J. (1986, Summer). Foreign language classroom anxiety. Modern Language Journal, 70 (2), 125-132.

James, W. (1910/1987). Writings 1902-1910. $2^{\text {nd }}$ ed. New York: Library of America.

Kafka, F. (1995). The complete stories. N.N. Glatzen (Ed.). New York: Schocken.

Lakoff, G. and Johnson, M. (1980). Metaphors we live by. Chicago: University of Chicago Press.

Lakoff, G. \& Turner, M. (1989). More than cool reason: A field guide to poetic metaphor. Chicago: University of Chicago Press.

Macaro, E. (2006) Strategies for language learning and for language use: revising the theoretical framework. Modern Language Journal, 90(3):320-337.

Ernesto Macaro, Suzanne Graham, and Robert Vanderplank. (2007). A Review of Listening Strategies: Focus on sources of knowledge and on success. In A.D. Cohen \& E. Macaro (Eds.), Thirty Years of research on language learner strategies (pp. xxx). Oxford, UK: Oxford University Press.

Maslow, A. (1964). Religion, values and peak experiences. New York: Viking.

Maslow, A. (1970). Religious aspects of peak experiences. New York: Harper \& Row.

Maslow, A. (1971). The farther reaches of human nature. New York: Viking. 
Naiman, N., Fröhlich, M., \& Todesco, A. (1975). The good second language learner. TESL Talk, 6, 68-75.

Norton, B. (2001). Non-participation, imagined communities, and the language classroom. In Breen, M. (ed.), Learner contributions to language learning: New directions in research (pp. 159-171) London: Longman.

Norton, B. \& Toohey, K. (2001). Changing perspectives on good language learners. TESOL Quarterly, 35(2), 307-322.

Norton, B. \&Toohey, K (Eds.). (2004), Critical pedagogies and language learning. Cambridge, UK: Cambridge University Press.

Nyikos, M. \& Oxford, R. (1993). A factor analytic study of language learning strategy use: Interpretations from information processing theory and social psychology. Modern Language Journal, 77(1), 11-22.

O'Malley, J.M. \& Chamot, A.U. (1990). Learning strategies in second language acquisition. Cambridge: Cambridge University Press.

O’Malley, J. M., Chamot, A. U., Stewner-Manzanares, G., Kupper, L., \& Russo, R. P. (1985). Learning strategies used by beginning and intermediate ESL students. Language Learning, 35, 21-46.

Oxford, R.L. (1990a). Language learning strategies: What every teacher should know. Boston: Heinle \& Heinle / Cengage.

Oxford, R.L. (1990b). Strategy Inventory for Language Learning. In Language learning strategies: What every teacher should know (Appendix). Boston: Heinle \& Heinle / Cengage.

Oxford, R.L. (1993). Style Analysis Survey. Tuscaloosa, AL: Oxford Associates.

Oxford, R. L. (1995). Style Analysis Survey. In J. Reid (Ed.), Learning styles in the ESL/EFL classroom (pp. 208-215). Boston: Heinle \& Heinle/ Thomson International.

Oxford, R.L. (1996). (Ed.), Language learning strategies around the world: Cross-cultural perspectives. Manoa: University of Hawai'i Press.

Oxford, R.L. (2009, Oct.). Crossing borders in learning new cultures and languages. Keynote address, $23^{\text {rd }}$ Biennial Congress, Deutsche Gesellschaft für Fremdsprachenforschung (German Association for Foreign Language Research) and the $6 \mathrm{oo}^{\text {th }}$ Anniversary of the Founding of Leipzig University, Leipzig, Germany.

Oxford, R. L. (2011a, Sept.). Optimizing language learning strategies: Ten guidelines to help teachers help their students become more strategic and effective. Keynote presentation, National Conference of the Federación Argentina de Asociaciónes de Profesores de Inglés (FAAPI, Argentine Federation of Teachers of English) and Asociación de Profesores de Inglés de Tucumán (APIT, Association of English Teachers of Tucumán), Tucumán, Argentina. 
Oxford, R.L. (2011b). Teaching and researching language learning strategies. Harlow, UK: Pearson Longman.

Oxford, R.L. (2012a). Meaning-making, border crossings, complexity, and new interpretive techniques: Expanding our understanding of learner narratives. Zeitschrift für Fremdsprachenforschung [Journal of Foreign Language Research].

Oxford, R.L. (2012b, Apr.). Ten strategic ways to help your students gain power in learning and communicating in English. Plenary, $12^{\text {th }}$ Annual ELT Conference, Sultan Qaboos University, Muscat, Sultanate of Oman.

Oxford, R.L. (2012c, Nov.). Expanding our understanding of the psychology of learning Chinese: Emotions, hot cognition, peak experience, flow, and inspired consciousness. Keynote presentation at the Chinese Language Education Forum, San Francisco, CA.

Oxford, R., Rubin, J., Chamot, A., Schramm, K., Lavine, R., Gunning, P., \& Nel, C. The learning strategy prism: perspectives of learning strategy experts. In this issue.

Oxford, R., Kawai, Y., Kawai, C., Ma, X., Meng, Y, Park, Y., \& Yang, N-D. Overcoming English-learning problems in East Asian contexts: Helping students become more strategic. In this issue.

Oxford, R.L. \& Lee, K.R. (2007). The learners' landscape and journey: A summary. In C. Griffiths (Ed.), Lessons from good language learners (pp. 306-3170. Cambridge, UK: Cambridge University Press.

Oxford, R.L. \& Lin, C-Y. (2011). Autonomous learners in digital realms: Exploring strategies for effective digital learning. In B. Morrison (Ed.), Independent language learning: Where innovation meets application. Hong Kong: Independent Learning Association / Hong Kong Polytechnic University Press.

Oxford, R.L., Tomlinson, S., Barcelos, A., Harrington, C., Lavine, R., Saleh, A., \& Longhini, A. (1998). Clashing metaphors about classroom teachers: Toward a systematic typology for the language teaching field. System, 26(1), 3-51.

Paige, R.M., Cohen, A.D., Kappler, B., Chi, J.C., \& Lassegard, J. (2006). Maximizing study abroad: A student's guide to strategies for language and culture learning and use. Minneapolis, MN: Center for the Advanced Research on Language Acquisition.

Ronstadt, L. (1976/1990). Love is a rose. Greatest hits. [CD]. New York: Electra/Time Warner.

Rubin, J. (1975). What the "good language learner" can teach us. TESOL Quarterly 9(1), 41-51.

Sarig, G. (1987). High-level reading in the first and in the foreign language: Some comparative process data. In J. Devine, P.L. Carrell, \& D.E. Eskey (Eds.), Research in reading in English as a second language (pp. 105-120). Washington, DC: TESOL. 
Scarcella, R. \& Oxford, R. (1992). The tapestry of language learning: The individual in the communicative classroom. Boston: Heinle \& Heinle.

Schmeck, R. (1988). Learning strategies and learning styles. New York: Plenum.

Selinker, L. (1972). Interlanguage. International Review of Applied Linguistics, 10(2): 209-231.

Stight, T.G. (1979). Metaphor and Thought: Educational uses of Metaphor. Cambridge University Press.

Vandergrift, L. (2003). Orchestrating strategy use: Toward a model of the skilled second language listener. Language Learning, 53(3), 463-496.

Virgil. (2006). The Aeneid. B. Knox (Ed.), R. Fagles (Trans). New York: Penguin.

Wenden, A.L. (1985). Learner strategies. TESOL Newsletter, 19(5), 1-7.

White, C., Schramm, K., \& Chamot, A.U. (2007). Research methods: Reexamining the strategy research toolbox. In A.D. Cohen \& E. Macaro (Eds.), Thirty years of research and theory (pp. 93-110). Oxford, UK: Oxford University Press.

Table 1. Eight Themes

\begin{tabular}{|c|l|}
\hline Stage of Analysis & \multicolumn{1}{|c|}{ Metaphors and Similes Arising in This Stage } \\
\hline \multirow{3}{*}{ Stage 1: } & creative construction \\
\cline { 2 - 2 } Open Coding & food and liquid \\
\cline { 2 - 2 } & movement and stasis \\
\cline { 2 - 2 } & music \\
\cline { 2 - 2 } & awakening, seeing, enlightening, and illuminating \\
\cline { 2 - 2 } & sports and business \\
\cline { 2 - 2 } & animals \\
\cline { 2 - 2 } & temperature \\
\hline
\end{tabular}

Table 2. Three Larger Themes

\begin{tabular}{|c|l|}
\hline Stage of Analysis & \multicolumn{1}{|c|}{ Metaphors and Similes Arising in This Stage } \\
\hline Stage 2: & awakening to strategies for the first time \\
\cline { 2 - 2 } Axial Coding & receiving and giving powerful gifts along the journey \\
\cline { 2 - 2 } & learner self-management \\
\hline
\end{tabular}

Table 3. Overarching Theme

\begin{tabular}{|c|l|}
\hline Stage of Analysis & \multicolumn{1}{c|}{ Theme Arising in This Stage } \\
\hline $\begin{array}{c}\text { Stage 3: } \\
\text { Selective Coding }\end{array}$ & $\begin{array}{l}\text { necessity of understanding learning strategies and applying } \\
\text { appropriate theories to explain them. }\end{array}$ \\
\hline
\end{tabular}

